\title{
The Root Causes of COVID-19 Screech for Compassion
}

\author{
Bassam Khoury ${ }^{1}$ (D)
}

Published online: 3 June 2020

(C) Springer Science+Business Media, LLC, part of Springer Nature 2020

Keywords Embodied $\cdot$ Embedded $\cdot$ Mindfulness $\cdot$ Meditation $\cdot$ Compassion $\cdot$ COVID-19

Aristotle proposed that unwise people react to things whereas wise people inquire about their root causes and aim to derive global principles. The pandemic of the 2019 novel coronavirus (causing the disease COVID-19) has expanded from Wuhan throughout China and has spread to more than 200 countries, with millions of people becoming infected and hundreds of thousands losing their lives to the disease (World Health Organization 2020). How did this happen, and what are the root causes?

The US Centers for Disease Control and Prevention (CDC) estimates that three-quarters of new or emerging diseases that infect humans originate in animals. Biological research suggests that COVID-19 and a high proportion of emerging and re-emerging infectious diseases are zoonoses derived from wildlife (Jones et al. 2008). Among the wildlife capable of transmitting viral infections to humans, bats seem to be in the frontline. In many respects, bats represent the perfect reservoir for emerging zoonotic pathogens because they harbor more zoonotic viruses per species than other animals such as rodents (Luis et al. 2013). Bats often live in large colonies or roosts; through flight, they can travel and disseminate viruses over considerable distances, and they enjoy remarkable longevity for their body size. Actually, some of the worst viral disease outbreaks in recent years, including the Severe Acute Respiratory Syndrome (SARS), the Middle East Respiratory Syndrome (MERS), Ebola, Marburg, and most likely now SARS-CoV-2 virus (or the 2019 novel coronavirus) originated in bats (University of California - Berkeley 2020). Henipaviruses, coronaviruses, filoviruses, and the rabiescausing lyssaviruses have all been shown to be transmissible from bats to humans. Research suggests that outbreaks of animal-borne and other infectious diseases, such as Ebola,

Bassam Khoury

bassam.el-khoury@mcgill.ca

1 Department of Educational and Counselling Psychology, McGill University, Quebec, Canada
SARS, bird flu, and now Covid-19, caused by a novel coronavirus, are on the rise (Smith et al. 2014). Pathogens are crossing from animals to humans, and many can spread quickly to new places.

The mechanisms of transmission of viruses such as SARSCoV-2 from bats to humans are not yet fully understood but can originate in a direct encounter between bats and humans; for example, during hunting as bats are consumed as food in some corners of the world. Another possible route of transmission involves inhalation of infectious particles by humans. These infective aerosols could arise from the secretions (e.g., saliva) of the bats (Wong et al. 2007). A third route for transmission is via a secondary intermediate vertebrate host serving as an amplifying host. This last scenario seems to fit other recent outbreaks of coronavirus-caused disease in humans, such as SARS, which arose from cat-like civets, and MERS, which arose from camels (Andersen et al. 2020).

Despite the obvious risk that bat viruses pose to human health, it must be acknowledged that most outbreaks of batborne zoonotic diseases are a consequence of human activities (Wynne and Wang 2013). Anthropogenic activities such as habitat loss, human encroachment, and the destruction of natural feeding and roosting habitats caused by urban sprawl and agricultural expansion are increasing the interactions between bats, humans, and livestock, thereby heightening the zoonotic potential conferred by those characteristics. Researchers have found that disrupting bat habitats and hunting them appears to stress the bats, causing them to shed even more virus in their saliva, urine, and feces, which can then infect other animals (University of California, Berkeley, 2020). Preliminary links have been established between loss of bat habitat and the spillover of bat viruses into other animals and humans (Jones et al. 2013). It is clear that human actions, such as the hunting of wild animals and mindless destruction of biodiversity, create the underlying favorable conditions for new viruses and diseases such as Covid-19, which threaten the existence of humanity itself, so how come humans still engage in destructive behaviors that threaten their own existence? 
Obvious reasons relate to accessing more food sources, exploiting additional land, extending agriculture, and furthering economic growth in order to provide resources for a growing human population. However, such motives, although important, do not explain why humans are failing to balance their needs with the well-being of the planet and animals. To answer this question, it is necessary to turn to Buddhist philosophy.

In Buddhism, the human condition is divided into two states: wholesome (kusala) and unwholesome (akusala) (Le Duc 2017). Unwholesome states lead to suffering and their origins are rooted in greed (rāga), hatred (dosa), and delusion (moha) (Kornfield 2011). Greed refers to any form of over-attachment to a sensory object. In this case, greed can be manifested through exploiting the planet, destruction of natural habitats, and taking advantage of animals, without ever attaining satisfaction. Hate is the opposite of greed, defined as the drive to avoid, resist, or even destroy things someone does not want. A subtle form of hatred is apathy. Apathy can be manifested by a lack of concern to the suffering of others and by justifying it at times as necessary for economic growth. Apathy plays a central role in the persistence of the ecological crisis (Le Duc 2017), the current surge of infectious diseases, and the transmission of viruses, such as the novel coronavirus, from animals to humans. Delusion is the inability to perceive reality and phenomena as they really are due to being trapped between the poles of greed and hatred/apathy (Khoury 2019). Another form of delusion is ignorance, such as denying empirical scientific facts in order to continue indulging in selfish desires while discounting the well-being of others, including animals and nature. Delusion can result from ideological notions supporting, for example, the stance that human beings can exercise absolute domination over nature and animals according to some sort of divine ordination, while denying the impacts of such actions on nature, animals, and therefore humans (Le Duc 2017).

Rectifying unwholesome states of mind requires engaging in daily practices of mindfulness and compassion. Mindfulness can be defined as an embodied non-judgmental attention and lucid awareness of oneself, others, and the environment (Khoury 2018; Khoury et al. 2017, 2019, 2020). Compassion can be defined as an embodied, integrated state with cognitive, affective, and behavioral dimensions that is characterized by an altruistic attitude, an emphatic concern, and a desire to alleviate suffering in oneself and in others (Khoury 2019). The Dalai Lama (2005a) included wisdom as an integral part of compassion, writing "Genuine compassion must have both wisdom and loving kindness. That is to say, one must understand the nature of the suffering from which we wish to free others (this is wisdom), and one must experience deep intimacy and empathy with other sentient beings (this is loving kindness)" (p. 49). Thus, compassion implies non-cruelty and harmlessness towards all sentient beings including animals (Finnigan 2017). Empirical studies have shown positive associations between mindfulness and nature connectedness (Howell et al. 2011), ecological sustainability (Amel et al. 2009; Jacob et al. 2009), and ecological behaviors (Geiger et al. 2018). Similar studies have shown positive associations between compassion to other human beings and pro-environmental tendencies, including values, intentions, and actions (Pfattheicher et al. 2016), as well as compassion towards animals in lab settings and the well-being of research personnel (LaFollette et al. 2020).

According to Buddhism, mindfulness and compassion should be taught as part of several complementary perspectives or ethics (Shonin et al. 2014). Such perspectives include the concepts of "non-self," "non-attachment," "impermanence," and "inter-connectedness." The term "non-self" refers to the realization that the self has no intrinsic existence (Dalai Lama 2005b). "Non-attachment" can be defined as the liberation from excessive craving or clinging that is favored by a vision of all objects and living beings as void of any lasting self and by the impermanent nature of all phenomena. "Impermanence" refers to the notion that all phenomena are transient occurrences and are subject to decay and dissolution (Rinpoche 1998). Finally, the term "interconnectedness" is used in Buddhism to refer to the interconnected nature of all phenomena (called also interbeing) (Nhat Hanh 1992).

Practices of mindfulness and compassion such as concentrative meditation (samatha), insight meditation (vipassana), and loving-kindness meditation (metta), along with nonformal mindfulness practices during daily activities, facilitate the recognition of the interconnectedness between humans, animals, and nature. This interconnectedness implies that the well-being and safety of humans depend on the well-being and safety of animals and of nature. In line with that, planetary health is emerging as a new discipline that focuses on the increasingly visible connections between the well-being of humans, other living things, and entire ecosystems (Vidal 2020). Mindfulness and compassion practices rooted in Buddhist ethics allow for overcoming greed by cultivating non-attachment, generosity, and humbleness; hatred through generating loving-kindness to all sentient beings and to nature; and delusion by recognizing the realities of impermanence, non-self, and interconnectedness.

Mindfulness and compassion practices do not preach apathy and non-doing, but rather the opposite. They cultivate a radical commitment to act in order to reduce the suffering of all sentient beings and to approach nature with awareness and kindness. A commitment to act should include the cultivation of social, racial, ethnic, and gender equalities based on a just, mindful, and non-competitive sharing of the natural resources and beauties of the planet. While social and political activism 
should be a core element of mindfulness and compassion practices, it is paramount that activism is conducted in a totally peaceful, non-violent, and wholesome manner. Any use of unwholesome or violent means would defeat the underlying purpose of such a movement.

In summary, biological, pharmacological, and medical interventions are highly needed to overcome the current COVID-19 pandemic. However, it is essential to understand its root causes in order to undertake a real, sustainable, and profound transformation of our state of mind, moment to moment, and therefore, in our actions towards all sentient beings and the surrounding environment. Mindfulness and compassion, when used skillfully and ethically, are among the most influential practices to facilitate change and transformation on an individual, inter-individual, social, environmental, and planetary scale. Perhaps, if we start listening to the screeches of bats with awareness and warm heartedness, and responding to them with compassion, we can start to reverse the destruction of the earth and save its sentient habitants, humans, and animals alike.

Compliance with Ethical Standards This commentary does not contain any studies with human participants performed by the author. No official funding was provided. The author has no competing interests.

Conflict of interest The authors declare that they have no conflict of interest.

\section{References}

Amel, E. L., Manning, C. M., \& Scott, B. A. (2009). Mindfulness and sustainable behavior: pondering attention and awareness as means for increasing green behavior. Ecopsychology, 1(1), 14-25. https:// doi.org/10.1089/eco.2008.0005.

Andersen, K. G., Rambaut, A., Lipkin, W. I., Holmes, E. C., \& Garry, R. F. (2020). The proximal origin of SARS-CoV-2. Nature Medicine. https://doi.org/10.1038/s41591-020-0820-9.

Finnigan, B. (2017). Buddhism and animal ethics. Philosophy Compass, 12(7), e12424. https://doi.org/10.1111/phc3.12424.

Geiger, S. M., Otto, S., \& Schrader, U. (2018). Mindfully green and healthy: an indirect path from mindfulness to ecological behavior [original research]. Frontiers in Psychology, 8(2306). https://doi. org/10.3389/fpsyg.2017.02306.

Howell, A. J., Dopko, R. L., Passmore, H.-A., \& Buro, K. (2011). Nature connectedness: associations with well-being and mindfulness. Personality and Individual Differences, 51(2), 166-171. https:// doi.org/10.1016/j.paid.2011.03.037.

Jacob, J., Jovic, E., \& Brinkerhoff, M. B. (2009). Personal and planetary well-being: mindfulness meditation, pro-environmental behavior and personal quality of life in a survey from the social justice and ecological sustainability movement. Social Indicators Research, 93(2), 275-294. https://doi.org/10.1007/s11205-008-9308-6.

Jones, K. E., Patel, N. G., Levy, M. A., Storeygard, A., Balk, D., Gittleman, J. L., \& Daszak, P. (2008). Global trends in emerging infectious diseases. Nature, 451(7181), 990-993. https://doi.org/10. 1038/nature 06536.

Jones, B. A., Grace, D., Kock, R., Alonso, S., Rushton, J., Said, M. Y., McKeever, D., Mutua, F., Young, J., McDermott, J., \& Pfeiffer, D.
U. (2013). Zoonosis emergence linked to agricultural intensification and environmental change. Proceedings of the National Academy of Sciences, 110(21), 8399-8404. https://doi.org/10.1073/pnas. 1208059110

Khoury, B. (2018). Mindfulness: embodied and embedded. Mindfulness, 9(4), 1037-1042. https://doi.org/10.1007/s12671-017-0858-z.

Khoury, B. (2019). Compassion: embodied and embedded. Mindfulness, 10(11), 2363-2374. https://doi.org/10.1007/s12671-019-01211-w.

Khoury, B., Knäuper, B., Pagnini, F., Trent, N., Chiesa, A., \& Carrière, K. (2017). Embodied mindfulness. Mindfulness, 8(5), 1160-1171. https://doi.org/10.1007/s12671-017-0700-7.

Khoury, B., Dionne, F., \& Grégoire, S. (2019). La pleine conscience incarnée : un concept unificateur entre les traditions orientales et occidentales de la pleine conscience. Annales MedicoPsychologiques, 177(7), 633-640. https://doi.org/10.1016/j.amp. 2018.04.010.

Khoury, B., Dionne, F., \& Grégoire, S. (2020). La dimension interpersonnelle de la pleine conscience. Annales MedicoPsychologiques, 178(3), 239-244. https://doi.org/10.1016/j.amp. 2018.10.018.

Kornfield, J. (2011). Bringing home the dharma: awakening right where you are. Shambhala Publications.

LaFollette, M. R., Riley, M. C., Cloutier, S., Brady, C. M., O'Haire, M. E., \& Gaskill, B. N. (2020). Laboratory animal welfare meets human welfare: a cross-sectional study of professional quality of life, including compassion fatigue in laboratory animal personnel [original research]. Frontiers in Veterinary Science, 7(114). https://doi.org/ 10.3389 /fvets.2020.00114.

Lama, D. (2005a). Essence of the heart sutra: the Dalai Lama's heart of wisdom teachings. Wisdom Publications.

Lama, D. (2005b). The many ways to nirvana. Mobius.

Le Duc, A. (2017). Buddhist communication of the true roots of the ecological crisis. Religion and Social Communication, 15(2), 125141.

Luis, A. D., Hayman, D. T. S., O'Shea, T. J., Cryan, P. M., Gilbert, A. T., Pulliam, J. R. C., Mills, J. N., Timonin, M. E., Willis, C. K. R., Cunningham, A. A., Fooks, A. R., Rupprecht, C. E., Wood, J. L. N., \& Webb, C. T. (2013). A comparison of bats and rodents as reservoirs of zoonotic viruses: are bats special? Proceedings of the Royal Society B: Biological Sciences, 280(1756), 20122753. https:// doi.org/10.1098/rspb.2012.2753.

Nhat Hanh, T. (1992). The sun my heart. Rider.

Pfattheicher, S., Sassenrath, C., \& Schindler, S. (2016). Feelings for the suffering of others and the environment: compassion fosters proenvironmental tendencies. Environment and Behavior, 48(7), 929-945. https://doi.org/10.1177/0013916515574549.

Rinpoche, S. (1998). The Tibetan book of living and dying. Rider.

Shonin, E., Van Gordon, W., \& Griffiths, M. D. (2014). The emerging role of Buddhism in clinical psychology: toward effective integration. Psychology of Religion and Spirituality, 6(2), 123-137. https:// doi.org/10.1037/a0035859.

Smith, K. F., Goldberg, M., Rosenthal, S., Carlson, L., Chen, J., Chen, C., $\&$ Ramachandran, S. (2014). Global rise in human infectious disease outbreaks. Journal of the Royal Society Interface, 11(101), 20140950. https://doi.org/10.1098/rsif.2014.0950.

University of California - Berkeley. (2020, February 10). Coronavirus outbreak raises question: why are bat viruses so deadly? Bats' fierce immune systems drive viruses to higher virulence, making them deadlier in humans. ScienceDaily. www.sciencedaily.com/releases/ 2020/02/200210144854.htm.

Vidal, J. (2020, March 18). 'Tip of the iceberg': is our destruction of nature responsible for Covid-19? The Guardian. https://www. theguardian.com/environment/2020/mar/18/tip-of-the-iceberg-isour-destruction-of-nature-responsible-for-covid-19-aoe 
Wong, S., Lau, S., Woo, P., \& Yuen, K.-Y. (2007). Bats as a continuing source of emerging infections in humans. Reviews in Medical Virology, 17(2), 67-91. https://doi.org/10.1002/rmv.520.

World Health Organization. (2020, 28 April). Rolling updates on coronavirus disease (COVID-19). WHO. https://www.who.int/ emergencies/diseases/novel-coronavirus-2019/events-as-theyhappen.
Wynne, J. W., \& Wang, L.-F. (2013). Bats and viruses: friend or foe? PLoS Pathogens, 9(10), e1003651-e1003651. https://doi.org/10. 1371/journal.ppat.1003651.

Publisher's Note Springer Nature remains neutral with regard to jurisdictional claims in published maps and institutional affiliations. 